Nevada

Environmental

Management

Operations Activity

\title{
Addendum to the
}

Closure Report for

Corrective Action Unit 165:

Area 25 and 26 Dry Well

and Washdown Areas,

Nevada Test Site, Nevada

Controlled Copy No.:

Revision No.: 0

October 2013

UNCLASSIFIED

/s/ Joseph P. Johnston

$10 / 22 / 2013$

Joseph P. Johnston, N-I CO

Date

Approved for public release; further dissemination unlimited.

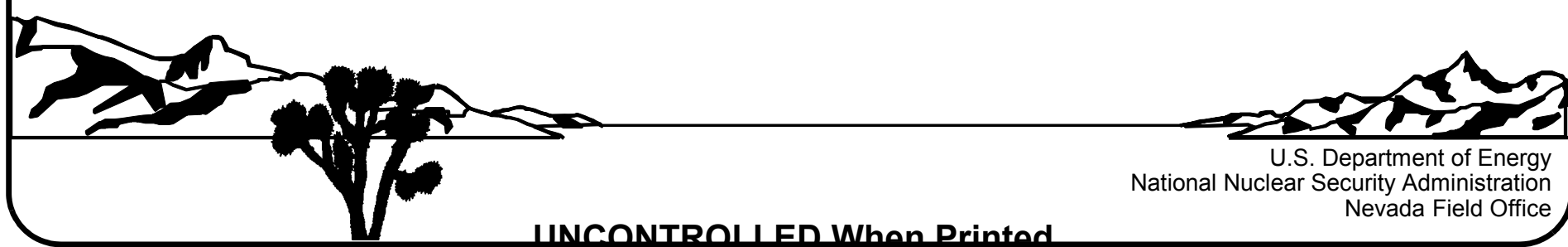


Available for sale to the public from:

U.S. Department of Commerce

National Technical Information Service

5301 Shawnee Road

Alexandria, VA 22312

Telephone: 800.553 .6847

Fax: 703.605.6900

E-mail: orders@ntis.gov

Online Ordering: http://www.ntis.gov/help/ordermethods.aspx

Available electronically at http://www.osti.gov/bridge

Available for a processing fee to U.S. Department of Energy and its contractors, in paper, from:

U.S. Department of Energy

Office of Scientific and Technical Information

P.O. Box 62

Oak Ridge, TN 37831-0062

Phone: 865.576 .8401

Fax: 865.576.5728

Email: reports@adonis.osti.gov

Reference herein to any specific commercial product, process, or service by trade name, trademark, manufacturer, or otherwise, does not necessarily constitute or imply its endorsement, recommendation, or favoring by the United States Government or any agency thereof or its contractors or subcontractors. 


\title{
ADDENDUM TO THE CLOSURE REPORT FOR CORRECTIVE ACTION UNIT 165: AREA 25 AND 26 DRY WELL AND WASHDOWN AREAS, NEVADA TEST SITE, NEVADA
}

\author{
U.S. Department of Energy, National Nuclear Security Administration \\ Nevada Field Office \\ Las Vegas, Nevada
}

Controlled Copy No.:

Revision No.: 0

October 2013

Approved for public release; further dissemination unlimited. 


\section{ADDENDUM TO THE CLOSURE REPORT FOR CORRECTIVE ACTION UNIT 165: \\ AREA 25 AND 26 DRY WELL AND WASHDOWN AREAS, NEVADA TEST SITE, NEVADA}

Approved by: IS/ Tiffany A. Lantow Date: 10/22/2013 Tiffany A. Lantow

Industrial Sites Activity Lead

Approved by: /S/ Robert F. Boehlecke Date: 10/22/20/3

Robert F. Boehlecke

Environmental Management Operations Manager 


\section{Addendum to the Closure Report for Removal of the Use Restriction}

This document constitutes an addendum to the Closure Report for Corrective Action Unit 165: Area 25 and 26 Dry Well and Washdown Areas, Nevada Test Site, Nevada (NNSA/NSO, 2005) as described in the document Recommendations and Justifications To Remove Use Restrictions Established under the U.S. Department of Energy, National Nuclear Security Administration Nevada Field Office Federal Facility Agreement and Consent Order (FFACO) dated September 2013. The Use Restriction (UR) Removal document was approved by the Nevada Division of Environmental Protection (NDEP) on October 16, 2013. The approval of the UR Removal document constituted approval of each of the recommended UR removals. In conformance with the UR Removal document, this addendum consists of:

- This page that refers the reader to the UR Removal document for additional information

- The cover, title, and signature pages of the UR Removal document

- The NDEP approval letter

- The corresponding section of the UR Removal document

This addendum provides the documentation justifying the cancellation of the UR for CAS 25-20-01, Lab Drain Dry Well. This UR was established as part of FFACO (FFACO, 1996; as amended) corrective actions and was based on the presence of tetrachloroethene (PCE) contamination at concentrations greater than the action level established at the time of the initial investigation. Although total petroleum hydrocarbon diesel-range organics (TPH-DRO) contamination at concentrations greater than the NDEP action level was present at the site, no hazardous constituents of TPH-DRO exceeded the U.S. Environmental Protection Agency (EPA) Region 9 preliminary remediation goals established at the time of the initial investigation.

Since this UR was established, practices and procedures relating to the implementation of risk-based corrective actions (RBCA) have changed. Therefore, this UR was re-evaluated against the current RBCA criteria as defined in the Soils Risk-Based Corrective Action Evaluation Process (NNSA/NSO, 2012). This re-evaluation consisted of comparing the original data (used to define the need for the UR) to the risk-based final action level (FAL) for PCE. The risk-based FAL was developed using the current Soils RBCA process.

The re-evaluation resulted in a recommendation to remove this UR because contamination is not present at this site above the risk-based FAL. Requirements for inspecting and maintaining this UR will be canceled, and the signage associated with the UR will be removed. This modification will not affect or modify any non-FFACO requirements for fencing, posting, or monitoring at this site. 


\section{References}

EPA, see U.S. Environmental Protection Agency.

FFACO, see Federal Facility Agreement and Consent Order.

Federal Facility Agreement and Consent Order. 1996 (as amended March 2010). Agreed to by the State of Nevada; U.S. Department of Energy, Environmental Management; U.S. Department of Defense; and U.S. Department of Energy, Legacy Management. Appendix VI, which contains the Industrial Sites Strategy, was last modified May 2011, Revision No. 4.

NAC, see Nevada Administrative Code.

Nevada Administrative Code. 2008. NAC 445A.2272, “Contamination of Soil: Establishment of Action Levels." Carson City, NV.

NNSA/NFO, see U.S. Department of Energy, National Nuclear Security Administration Nevada Field Office.

NNSA/NSO, see U.S. Department of Energy, National Nuclear Security Administration Nevada Site Office.

U.S. Department of Energy, National Nuclear Security Administration Nevada Field Office. 2013. Recommendations and Justifications To Remove Use Restrictions Established under the U.S. Department of Energy, National Nuclear Security Administration Nevada Field Office Federal Facility Agreement and Consent Order, Rev. 0, DOE/NV--1510. Las Vegas, NV.

U.S. Department of Energy, National Nuclear Security Administration Nevada Site Office. 2005. Closure Report for Corrective Action Unit 165: Area 25 and 26 Dry Well and Washdown Areas, Nevada Test Site, Nevada, Rev. 0, DOE/NV--1092. Las Vegas, NV.

U.S. Department of Energy, National Nuclear Security Administration Nevada Site Office. 2012. Soils Risk-Based Corrective Action Evaluation Process, Rev. 0, DOE/NV--1475. Las Vegas, NV.

U.S. Environmental Protection Agency. 2004. "Region 9 PRG Table.” As accessed at http://www.epa.gov/region09/superfund/prg/files/04prgtable.pdf on 18 March 2013. San Francisco, CA. 
Nevada

Environmental

Management

Operations Activity

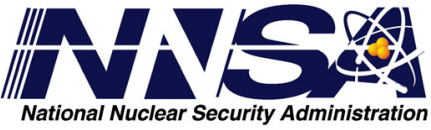

Recommendations and Justifications

To Remove Use Restrictions Established

under the U.S. Department of Energy,

National Nuclear Security Administration

Nevada Field Office

Federal Facility Agreement

and Consent Order

Controlled Copy No.: _

Revision No.: 0

September 2013

UNCLASSIFIED

Is/ Joseph P. Johnston, N-I CO 09/09/2013

Approved for public release; further dissemination unlimited.
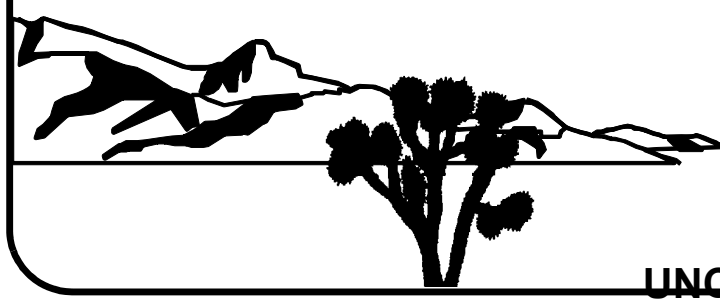
Available for sale to the public from:

U.S. Department of Commerce

National Technical Information Service

5301 Shawnee Road

Alexandria, VA 22312

Telephone: 800.553 .6847

Fax: 703.605.6900

E-mail: orders@ntis.gov

Online Ordering: http://www.ntis.gov/help/ordermethods.aspx

Available electronically at http://www.osti.gov/bridge

Available for a processing fee to U.S. Department of Energy and its contractors, in paper, from:

U.S. Department of Energy

Office of Scientific and Technical Information

P.O. Box 62

Oak Ridge, TN 37831-0062

Phone: 865.576 .8401

Fax: 865.576.5728

Email: reports@adonis.osti.gov

Reference herein to any specific commercial product, process, or service by trade name, trademark, manufacturer, or otherwise, does not necessarily constitute or imply its endorsement, recommendation, or favoring by the United States Government or any agency thereof or its contractors or subcontractors. 


\title{
RECOMMENDATIONS AND JUSTIFICATIONS TO REMOVE USE RESTRICTIONS ESTABLISHED UNDER THE U.S. DEPARTMENT OF ENERGY, NATIONAL NUCLEAR SECURITY ADMINISTRATION NEVADA FIELD OFFICE FEDERAL FACILITY AGREEMENT AND CONSENT ORDER
}

\author{
U.S. Department of Energy, National Nuclear Security Administration \\ Nevada Field Office \\ Las Vegas, Nevada
}

Controlled Copy No.:

Revision No.: 0

September 2013

Approved for public release; further dissemination unlimited. 


\subsection{CAU 165, CAS 25-20-01 - Lab Drain Dry Well}

\subsection{CAS Description}

The Lab Drain Dry Well is located approximately 55 feet (ft) north of Building 4215 in the Central Support Area of Area 25 on the NNSS. System components include a concrete dry well and two waste pipes. The chemical waste pipe includes $55 \mathrm{ft}$ of 6-inch (in.) vitrified clay pipe (VCP) from the north side of Building 4215 to the dry well. Another waste pipe was discovered during field activities. This waste pipe is also a 6 -in. VCP and is $60 \mathrm{ft}$ long running east-west from a pipe stickup into the dry well. This pipe was unknown before the investigation; however, personnel who work in Building 4215 reported that there used to be trailers in the vicinity of the stick-up and that it was probably a sanitary pipe. The dry well is a 4-by-8-ft precast concrete manhole ring with an open bottom and is filled with 0.75 - to 1.5 -in. gravel to a minimum depth of $4 \mathrm{ft}$. The manhole to the dry well is set to surface grade (NNSA/NSO, 2004b). As a best management practice, during closure activities the dry well was backfilled to grade with clean soil (NNSA/NSO, 2005a).

\subsection{Current UR Description}

The future use of any land related to this CAS is restricted from any DOE or U.S. Air Force (USAF) activity that may alter or modify the containment control, as approved by the State of Nevada and identified in the CAU CR or other CAU documentation, unless appropriate concurrence is obtained in advance. Two UR warning signs were posted to warn against intrusive activity; no fencing around the UR is required. Annual site inspections are conducted to ensure the signs are in good repair and that the UR is maintained (NNSA/NSO, 2005a).

\subsection{Basis for Current UR}

Samples were analyzed for VOCs, SVOCs, RCRA metals, TPH-diesel-range organics (DRO), TPH-gasoline-range organics (GRO), PCBs, gamma spectroscopy, isotopic uranium (U), isotopic plutonium $(\mathrm{Pu})$, and strontium (Sr)-90. The analytical results for soil samples collected at the CAS indicated that no SVOCs, RCRA metals, PCBs, TPH-GRO, or radionuclides were detected above PALs. Tetrachloroethene (PCE), a VOC, exceeded the EPA Region 9 PRGs, while TPH-DRO 
concentrations exceeded the NDEP action level of $100 \mathrm{mg} / \mathrm{kg}$. No hazardous constituents of TPH-DRO exceeded the EPA Region 9 PRGs (NNSA/NSO, 2004b).

The concentrations of both PCE and TPH-DRO decreased with depth and were below PALs within $2.5 \mathrm{ft}$ vertically of the dry well base. Step-out samples were analyzed for PCE only, as PCE is more mobile than TPH-DRO. Step-out sample results indicated that the PCE did not migrate $15 \mathrm{ft}$ laterally in significant concentrations (NNSA/NSO, 2004b).

Table 3-1 contains analytical results of COCs at CAS 25-20-01 that are the basis for the current UR. The sample matrix for all samples is soil.

Table 3-1

Sample Results for COCs at CAS 25-20-01 Used To Establish Current UR

\begin{tabular}{|c|c|c|c|}
\hline \multirow{2}{*}{ Sample ID } & \multirow{2}{*}{$\begin{array}{c}\text { Depth } \\
\text { (ft bgs) }\end{array}$} & TPH-DRO & PCE \\
\cline { 3 - 4 } & & $\begin{array}{c}\text { PAL } \\
\mathbf{1 0 0} \mathbf{~ m g / k g}\end{array}$ & $\begin{array}{c}\text { PAL } \\
\mathbf{1 9} \mathbf{~ m g} / \mathbf{k g}\end{array}$ \\
\hline \hline $165 \mathrm{~A} 001$ & $9.0-10.0$ & $170(\mathrm{D}, \mathrm{M}, \mathrm{Z})$ & -- \\
\hline $165 \mathrm{~A} 005$ & $9.0-10.0$ & -- & 110 \\
\hline
\end{tabular}

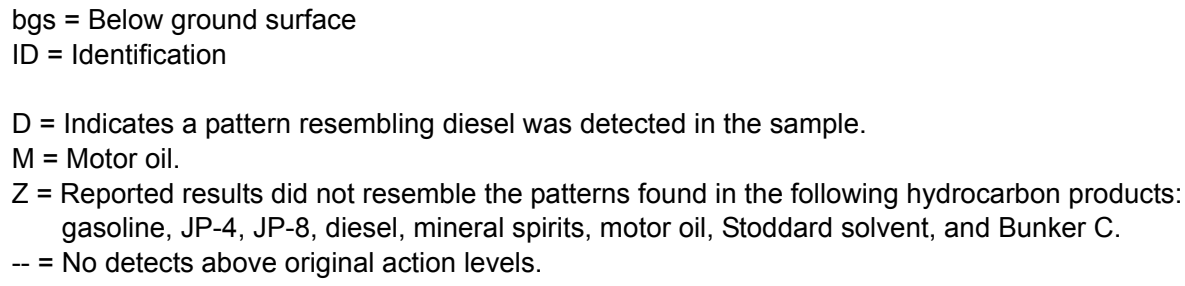

\subsection{Basis for UR Modification}

The site-specific Tier 2 IA FAL for PCE was calculated using the EPA Region 9 RSLs for Chemical Contaminants at Superfund Sites Calculator (EPA, 2013b) and the latest input values (NNSA/NFO, 2013c). Table 3-2 presents the sample result for PCE that is the basis for the current UR and the revised site-specific Tier 2 IA FAL. Because no hazardous constituents of TPH-DRO were detected in any of the samples at concentrations greater than their respective FALs, and because the PCE does not exceed the Tier 2 IA FAL, no contaminants are present at this site. 
Table 3-2

\section{Revised IA Tier 2 FAL for PCE at CAS 25-20-01}

\begin{tabular}{|c|c|c|}
\hline \multirow{2}{*}{ Sample ID } & $\begin{array}{c}\text { Depth } \\
\text { (ft bgs) }\end{array}$ & \begin{tabular}{c} 
PCE \\
\cline { 3 - 3 }
\end{tabular} \\
& & $\begin{array}{c}\text { IA FAL } \\
\mathbf{1 7 5} \mathbf{~ m g} / \mathbf{k g}\end{array}$ \\
\hline \hline $165 \mathrm{A005}$ & $9.0-10.0$ & 110 \\
\hline
\end{tabular}

\subsection{Proposed Modification}

Remove the FFACO UR and associated signs, and discontinue annual inspection and maintenance requirements at this site. These modifications will not affect or modify any non-FFACO requirements at this site. 
EPA, see U.S. Environmental Protection Agency.

NNSA/NFO, see U.S. Department of Energy, National Nuclear Security Administration Nevada Field Office.

NNSA/NSO, see U.S. Department of Energy, National Nuclear Security Administration Nevada Site Office.

U.S. Department of Energy, National Nuclear Security Administration Nevada Field Office. 2013c. Written communication. Subject: Soils Risk-Based Corrective Action Evaluation Process. Las Vegas, NV.

U.S. Department of Energy, National Nuclear Security Administration Nevada Site Office. $2004 b$. Corrective Action Decision Document for Corrective Action Unit 165: Area 25 and 26 Dry Well and Washdown Areas, Nevada Test Site, Nevada, Rev. 1, DOE/NV--879-Rev. 1. Las Vegas, NV.

U.S. Department of Energy, National Nuclear Security Administration Nevada Site Office. 2005a. Closure Report for Corrective Action Unit 165: Area 25 and 26 Dry Well and Washdown Areas, Nevada Test Site, Nevada, Rev. 0, DOE/NV--1092. Las Vegas, NV.

U.S. Environmental Protection Agency. 2013b. Regional Screening Levels for Chemical Contaminants at Superfund Sites (RSL Calculator). As accessed at http://epaprgs. ornl.gov/cgi-bin/chemicals/csl_search on 19 February. Prepared by EPA Office of Superfund and Oak Ridge National Laboratory. 


\title{
Library Distribution List
}

\author{
$\underline{\text { Copies }}$ \\ U.S. Department of Energy \\ 1 (Uncontrolled, electronic copy) \\ Office of Scientific and Technical Information \\ P.O. Box 62 \\ Oak Ridge, TN 37831-0062 \\ Southern Nevada Public Reading Facility \\ 2 (Uncontrolled, electronic copies) \\ c/o Nuclear Testing Archive \\ P.O. Box 98521, M/S 400 \\ Las Vegas, NV 89193-8521 \\ Manager, Northern Nevada FFACO \\ 1 (Uncontrolled, electronic copy) \\ Public Reading Facility \\ c/o Nevada State Library \& Archives \\ 100 N. Stewart Street \\ Carson City, NV 89701-4285
}

